\title{
INTERACTION OF LAW ENFORCEMENT AUTHORITIES AS THE BASIS OF EFFECTIVE COMBATING ECONOMIC CRIME
}

\author{
Vyacheslav Nekrasov ${ }^{1}$ \\ Vadym Melnyk ${ }^{2}$ \\ Konstiantyn Kryvosheiev ${ }^{3}$ \\ Yurii Kiiashko ${ }^{4}$ \\ Oleh Yemets ${ }^{5}$
}

\begin{abstract}
The relevance of this article is due to the place of law enforcement agencies in the system of economic security of Ukraine. The purpose of the article is to conduct a scientific study on the issues of organizing the interaction of

fact that this study may serve as a basis for outlining future changes to the current legislation of Ukraine on increasing the level of cooperation of law enforcement agencies to ensure the economic security system in Ukraine.
\end{abstract} law enforcement agencies to ensure the economic security of Ukraine. The leading research methods are general scientific and special research methods, including methods of logic, analysis, comparison etc. The results of this study are a theoretical and practical study of the economic security sphere in Ukraine, outlining general scientific categories and identifying ways to increase the level of cooperation of law enforcement agencies in this field. The significance of the obtained results is reflected in the

Keywords: economic security, law enforcement interaction, national economy, state interests, intellectualization of crime.

\section{Introduction}

From the very beginning of the existence of an independent Ukraine, one of its important tasks has been to create and maintain favorable conditions for ensuring the system of economic security of the state. The implementation

National Academy of Internal Affairs, Solomianska Square, 1, Kyiv, 03035, Ukraine. E-mail: ${ }^{1}$ nekrasov.v@politechnika.pro

Sumy State University, Rimsky-Korsakov Street, 2, Sumy, 40007, Ukraine ${ }^{2}$

Sumy State University, Rimsky-Korsakov Street, 2, Sumy, 40007, Ukraine ${ }^{3}$

Sumy State University, Rimsky-Korsakov Street, 2, Sumy, 40007, Ukraine ${ }^{4}$

National Academy of Internal Affairs, Solomianska Square, 1, Kyiv, 03035, Ukraine ${ }^{5}$ 
of this task is entrusted to the domestic law enforcement agencies, the systematic effective work of many of which affects the various links and spheres of the national economy. For example, only by the results of the work of tax police units of the State Fiscal Service of Ukraine in 2019, the total economic effect is 111.1 billion hryvnas (Results of the work..., 2019), and as a result of the activities of the National Anti-Corruption Bureau of Ukraine in the second half of last year, 601.59 million hryvnas was reimbursed (Report of the National Anti-Corruption Bureau..., 2019). Since the summer of 2019 , as a result of the set of appropriate measures implementation, the Security Service of Ukraine in the economic sphere has made it impossible to incur losses to the state in the amount of more than 25.7 billion hryvnas (Bakanov, 2020).

At the same time, despite the tendency to reduce crime rates (Kniaziev, 2020) and the World Bank's projections for Ukraine's GDP growth by $3.7 \%$ in 2020 and by $4.2 \%$ in 2021 , the issue of ensuring the country's economic security system remains extremely relevant (World Bank forecasts ..., 2020). After all, the amount of losses from the state budget, due to corruption offenses alone, reaches more than 180 billion hryvnas every year (Bihus, 2020) which, objectively, needs appropriate government response.

From the point of view of law enforcement, this is primarily due to the need to counter a wide range of real threats to the national economy, which are constantly growing. This, in particular, is due to the intensification of transnationalization processes, the intellectualization of criminality, the development of information and communication technologies etc. These factors determine the need to find ways to improve the efficiency of law enforcement agencies in the specified direction. Undoubtedly, one of them is to deepen the interaction of the latter in the issues of counteracting the threats to the economic security system of Ukraine. As many years of practice show, there are cases of need for rapid consolidation of existing efforts in the work of these entities in order to effectively protect the economic interests of the state.

Taking into account the fact that the interaction of domestic law enforcement agencies is an important aspect of the latter's activities in order to ensure the proper functioning of the 
economic security system of Ukraine, there is an objective need to find ways to improve the current legal regulation of this area (Harust and Melnyk, 2019). To achieve this goal, the authors have set the following tasks:

1) to analyze common approaches to such concepts as "interaction" and "law enforcement" and to define their essence;

2) to propose the author's definition of the definition of "law enforcement cooperation on ensuring the economic security of Ukraine";

3) to outline the subjective composition of the main national law enforcement agencies authorized to ensure the economic security of Ukraine;

4) to propose ways of increasing the level of cooperation between law enforcement agencies to ensure the economic security of Ukraine.

\section{Materials and Methods}

The following methods were used during the research: general theoretical (analysis, synthesis, concretization, generalization, analogy method, modeling); empirical methods (investigation of the system of economic security of bodies functioning and features of domestic law enforcement agencies interaction, research of regulatory-scientific and methodological literature on the subject, scientific research and conclusions). Investigating the aspect of law enforcement cooperation on ensuring the economic security system of Ukraine, for the sake of completeness and comprehensiveness, the focus should be on the importance of the terms "interaction" and "law enforcement agencies". It is also important to determine the subjective composition of the main law enforcement agencies authorized to perform this task.

Regarding the category of "interaction", it has repeatedly been in the field of view of various branches of science representatives. Interaction is considered one of the basic philosophical, ontological categories. It is a phenomenon of communication, influence, transition, development of different objects under the influence of interaction on each other, on other objects. Interaction is the initial, generic category. Any phenomenon, object, state can be understood (known) only in connection and relations with others, because everything in the world is interconnected. Interaction, involving at least two objects at the same time, means 
that each of them is also interacting with the other (Khrebyna, 2006).

It is one of the forms of various legal relationships participant's activity, determining the structural construction and organization of the relevant material system. The need for interaction has existed and will always exist, which obviously also concerns the problem of ensuring the system of economic security of Ukraine, given the multifaceted and branched components of the latter (Harust et al., 2019). There is no doubt that the implementation of the state policy on the protection of the economic component requires the implementation of a wide range of measures, including, among others, the joint concerted work of the relevant law enforcement actors. The need for consolidation of efforts in the implementation of the law enforcement function is recognized by the employees of the analyzed entities. Thus, according to the results of the 2016 survey, $32 \%$ of respondents believe that any business contacts are interaction; $24 \%$ believe that interaction is needed only in the system of operational units; $44 \%$ allow interaction at the pre-trial stage of criminal proceedings and during the implementation of operational investigative measures (Maliuha, 2016). The very concept of "interaction", while being the object of scientific interest on the part of many scientists, has long been an ambiguous interpretation. For example, when analyzing interaction as a philosophical category, it is important that it reflects the processes of objects (entities) influence on each other, their mutual conditionality and the production of one object by another (Morozov, 2015). In the forensic aspect, the interaction is proposed to be considered in the following variations:

1) the coordinated activity of two or more entities that solve the same problem (tasks) by different methods and means of law enforcement agencies whose subjects carry out crime detection and investigation;

2) the organizational and tactical method of acquiring new knowledge, which is not always possible for each subject of interaction;

3) administrative activities based on the mutual trust of the parties united by the sole task of detecting and investigating crime and combating crime (Saltevskyi, 2005). 
Interaction, as a management process, consists in the activity of several (at least two) entities that influence each other and the object by the means and methods inherent in each participant to achieve a common goal (Nazar, 2006). Analyzing these approaches, you can come to a natural conclusion that the dominant view is the joint activity of two or more entities aimed at achieving one or more goals. This activity is also characterized by the following:

1) exists only in the presence of two or more co-existing systems with related functions;

2) it occurs when the systems function simultaneously;

3) the presence of interacting elements of similar properties;

4) when interacting the qualitative characteristics of the interaction objects change;

5) the ability of each interaction object to initiate it;

6) the possibility of negative and positive consequences of interaction;

7) the commonality of the purpose, means and activities of the detached interacting entities (Oliinyk, 2012).
At the same time, it is also a structural concept, when interaction acts as an integrating factor, by means of which the integration of some parts into a certain type of whole (Maliuha, 2016). It should also be assumed that only with the implementation of this activity it is possible to obtain the necessary result, including the provision of effective systematic protection of the economic interests of the Ukrainian state.

\section{Results and Discussion}

Having considered and analyzed the views of different branches of science representatives concerning the definition of "interaction", and also acquainted with its key features, we propose our own vision of the concept "interaction of law enforcement agencies to ensure the economic security of Ukraine". In our opinion, it should be considered the activities of the relevant law enforcement agencies to counteract the threats to the economic security system of Ukraine with a view to rational use of available resources and to facilitate the prompt and effective fulfillment of the tasks set, within their competence, stipulated by the norms of the current legislation agreed on by time, place and content. 
The organization and implementation of cooperation in the aspect of ensuring the economic security of Ukraine is of paramount importance for the modern state in terms of law enforcement. Considering their role in the state mechanism, the range of tasks and specificity of the latter's implementation of all legal measures is an objective and urgent need in the current environment (Oliinyk, 2012). This is also due to the existence of a wide range of available and potential exogenous and endogenous factors for the national economy, the number of which, as well as the degree of existing and likely destructive impact, is constantly changing (Syroid et al., 2019).

According to A. Kulish, these entities are specially authorized state bodies, which ensure the observance and realization of citizens' rights and freedoms, law and order with observance of the rules and procedures established by law in accordance with their competence (Kulish, 2005). A. Kuchuk notes that these are specially authorized state bodies, which are vested with statepower powers for the purpose of professional exercise on the basis and in accordance with the law, and in cases established by law, - in an appropriate procedural form, with the application of legal means, activities aimed at the protection of human and citizen's rights and freedoms, law and order, all regulated by the law of public relations (Kuchuk, 2007). S. Rossokha assures that this entity is a state body, which is conferred by the Constitution and the laws of Ukraine with a certain amount of rights and responsibilities to protect the rights and legitimate interests of citizens, legal entities, society and the state by committing specific acts of coercive nature, which are conducted in a specific procedural form (Rossokha, 2016). As we can see, scientists agree that this is a circle of subjects, which, in accordance with the current legislation, is vested with some competence in the protection of the rights and legitimate interests of individuals.

It is considered expedient that by the term "law enforcement agencies" we shall mean public authorities, empowered with authority in accordance with applicable law and carry out, within their competence, law enforcement activities (Harust and Melnyk, 2019). The said activity is aimed at ensuring the protection of the rights of participants in a particular sphere of legal relations, including economic relations, by means 
of government-sanctioned measures of influence. The basis of state lawenforcement activities is based on the need to ensure the regime of legality of steadfast observance of rights, freedoms, as well as the interests of society and the state protected by law.

Obviously, these legal phenomena are the protection of law through the enforcement of law enforcement agencies by the state authorities, as well as providing them with a regime of lawfulness are organically interconnected. Thus, the law enforcement activity of the state, its directions and forms of implementation, directly influence the formation of the regime of law and order. These phenomena, when systematically interconnected and interdependent, complement, develop and correct each other (Huliahyn, 2015). That means, that the analyzed subjects, being endowed with power, are obliged to take a set of legal measures aimed at ensuring the protection of the rights of participants in the respective relations. Moreover, all such measures are characterized by clear regulation, in particular concerning the grounds and the procedure for their application.
In the aspect of ensuring the system of economic security of Ukraine, undoubtedly, the productive activity of all authorized national law enforcement agencies is of great importance. However, given the tasks and functions of these entities, it is reasonable to assume that some of them play a special role in this process. At the present stage, these include:

1) bodies of the prosecutor's office;

2) the National Police of Ukraine;

3) Security Service of Ukraine;

4) units of the tax police of the State Fiscal Service (pending completion of the steps to create a central executive body charged with the duty to prevent, detect, termination, investigation and disclosure of criminal offenses that are the subject of financial interests of the state and / or local self-government, which will be attributed to its jurisdiction (Harust and Melnyk, 2019);

5) National Anti-Corruption Bureau of Ukraine;

6) the State Bureau of Investigation;

7) Office of financial control. Accordingly, we will pay attention to the 
issues of organization and interaction of these law enforcement entities.

However, it is of the utmost importance to find out the key areas of activity of these entities for the practical implementation of joint measures that will be essential for the economic component of national security. Analyzing the current regulatory support, which is the basis for the work of these law enforcement agencies, as well as assessing the likely destructive impact on the national economic sector, we can come to a legitimate conclusion that these include operational investigative activities and pre-trial investigation of relevant crime (“economic crimes"). A significant role is also played by preventive activities, conducting state financial control, etc. However, given the key role, the appointment of law enforcement agencies in the modern domestic state mechanism and the specificity of threats to the economic component is precisely counteracting crime, through investigative or operational search activities remain one of the most effective and commonly used ways to facilitate proper functioning of the economic security system of Ukraine.
This is also due to the existence of the phenomenon of economic crime, its progression and a marked increase in the impact on the economic situation in Ukraine. It is a phenomenon peculiar to any state, which is expressed in socially dangerous, unlawful highly intellectual acts which result in the violation (or there are substantial grounds for the violation) of the normal conditions for the functioning of a particular sphere of the national economy due to the redistribution of economic resources (Harust et al., 2019).

In today's realities, which is characterized by increasing pressure from this phenomenon, one of the many consequences is an increase in the number of economic crimes. Thus, according to a survey in $2018,48 \%$ of Ukrainian organizations have been affected by economic crime and fraud in the last two years, compared with $43 \%$ in 2016. Bribery and corruption remain one of the main types of economic crimes negatively impacted by Ukrainian organizations $-73 \%$ of respondents said their organizations had been victims of bribery and corruption in the last two years (Klimchak, 2019). It is obvious that such a negative tendency to commit economic crimes requires measures to be 
taken to counteract them, creating favorable conditions for conducting legal economic activities. As already noted, the key role in this area is given to law enforcement agencies, whose work is aimed at protecting the economic interests of the state (Harust et al., 2019). There is no doubt that this is essential to the issue of effective systematic interaction of law enforcement agencies in the outlined direction.

At the same time, examining the current legal and regulatory provision, which regulates the activities of the above-mentioned law enforcement agencies, it is concluded that there is no act in the national legal plane that comprehensively regulates the issues of organization and interaction of these entities with the state economic security system. Certainly, a number of important aspects have been addressed in some laws of Ukraine, international treaties, as well as by-laws. The common practice of approving joint orders on the order of interaction of individual law enforcement agencies among the proposed subjects of the economic security system of Ukraine. One example is the Instruction on the cooperation of law enforcement agencies in the fight against organized crime, approved by
Order of the Ministry of Internal Affairs of Ukraine and the Central Administration of the Security Service of Ukraine No. 317/235 (Order of the Ministry of Internal Affairs..., 2011). Its corresponding provisions provide the basic principles, directions, forms and levels of interaction, determine the peculiarities of preparation for such a variety of activities, joint activities, exchange of information between special units and more.

Therefore, one of the acute problems today is the lack of a document that would regulate the interaction of these law enforcement agencies to ensure the economic security of Ukraine. The necessity of such an act, which is primarily aimed at the economic component of the national security sector, is, in our opinion, conditioned by the basic need of today - any legal support to the development of the domestic economy. One of the important prerequisites for achieving this goal is first and foremost due to the existence of the act specified. Objectively, this, in turn, should serve:

1) effective counteraction to threats to the system of economic security of Ukraine, especially at the 
stage of their emergence and gradual progress;

2) improvement of the existing administrative and legal regulation for the activity of law enforcement agencies on ensuring the system of economic security of Ukraine;

3) rational use of all logistical resources and human resources;

4) consolidation of existing efforts to counteract exogenous and endogenous negative factors through legal means;

5) a real increase in the level of efficiency of the all analyzed activity of the law enforcement agencies as subjects of ensuring the economic security system of Ukraine and etc.

An important component of the structure of such an act should be the order of regulation of administrative and legal forms of interaction of all these entities. Such forms are an external expression of the concerted activity of its subjects for the purpose of completing the tasks assigned to them (Orlova, 2008). They have long positioned themselves as a direct attribute of administrative activity that provides interconnection, the most appropriate dependence of the elements of the activity, which brings in their correlation order, stability and dynamism (Marchenko, 2009). Thanks to administrative and legal forms, it is possible to identify and characterize the external manifestation of the activities of law enforcement agencies, including their interaction during the direct implementation of measures to ensure the economic security of Ukraine.

Focusing on the national legislative framework, in this context we should single out the already mentioned Instruction on law enforcement cooperation in the field of organized crime, approved by Order of the Ministry of Internal Affairs of Ukraine and the Central Administration of the Security Service of Ukraine No. 317/235 (Order of the Ministry of Internal Affairs..., 2011). It is difficult to doubt that a high degree of organization is inherent in a significant number of threats to the national economy. This often involves the joint activity of several persons in order to, in the context of our study, cause economic harm to the state. It is therefore clear that the forms of law enforcement cooperation proposed in this act will take place during the implementation of joint measures to ensure the economic security of Ukraine. 
According to paragraph 5 of this document, the following forms are recognized:

1) conducting a joint analysis of the status, structure of organized crime, causes and conditions contributing to the activities of organized groups, forecasting trends in the spread of organized crime;

2) exchange of operational information of interest for the fight against organized crime;

3) development and implementation of joint programs, plans for combating organized crime;

4) creation of working groups for preparation of bills, proposals for amendments to legislation;

5) conducting coordinated operational search, preventive and other measures;

6) preparation and holding of joint colleges, meetings, seminars on improving interaction;

7) curriculum development and training in the vocational training system;

8) improving international cooperation in the fight against organized crime;
9) informing the public about the results of activities in the fight against organized crime (2011).

There are also some other perspectives on the forms of law enforcement interaction in research circles. One of the commonly held opinions is that in the context of combating economic crime the following forms of interaction are the most effective and widespread in practice:

1) exchange of information on various violations in the sphere of economy;

2) non-procedural advisory assistance of employees of control bodies to operative employees, investigators on issues requiring special knowledge;

3) an audit on the initiative of the relevant units of law enforcement agencies;

4) interrogation of employees of control bodies as witnesses in a criminal case on issues requiring special knowledge;

5) involvement of employees of control bodies in participation in carrying out separate investigative actions as specialists (Korystin, 2010). 
The results of the study are as follows:

1) the widespread existing approaches to such concepts as "interaction" and "law enforcement" are analyzed and their essence is defined;

2) the author's definition of the concept "law enforcement cooperation to ensure the economic security of Ukraine" is proposed;

3) the subjective composition of the main national law enforcement agencies authorized to ensure the economic security of Ukraine is outlined;

4) the ways to increase the level of cooperation between law enforcement agencies to ensure the economic security of Ukraine are proposed.

It is considered expedient to propose our own vision of a complex of forms of law enforcement cooperation on ensuring the economic security of Ukraine. In our opinion, these should include the following:

1) carrying out an analysis of the situation, assessing the structure of threats to the economic security system of Ukraine, identifying factors that contribute to the emergence and / or development of these destructive factors;
2) forecasting trends in economic crime and other threats to the economic security system of Ukraine;

3) assessment of probable consequences of the impact of threats on the national economy;

4) exchange of operative information on threats to the economic security system of Ukraine;

5) development and implementation of joint programs, plans to counter threats to the economic security system of Ukraine;

6) issue of joint legal acts, the provisions of which are devoted to measures for the implementation of state policy on ensuring the system of economic security of Ukraine;

7) creation of working groups for participation in the preparation of drafts of relevant normative legal acts, proposals for amendments and amendments to the current legislation;

8) carrying out measures, coordinated in time, place and content (preventive, operative-search, investigative, etc.) with direct counteraction to threats to the economic security system of Ukraine;

9) development of joint international cooperation on 
counteracting threats to the economic security system of Ukraine;

10) development of training programs and trainings for improving the professional level of law enforcement officers on counteracting threats to the economic security system of Ukraine;

11) jointly informing the public about the results of activities to counter the threats to the economic security system of Ukraine.

In the opinion of the authors, the recognition of the complex of the above mentioned forms of the analyzed law enforcement agencies interaction by the state is an important and necessary measure in the conditions of today. We believe that this will help to increase the efficiency of each of them in the fulfillment of one of the key constitutional tasks - the protection of the economic component of national security.

\section{Conclusion}

The generality suggests that one of the many important tasks of the state is to ensure the proper functioning of Ukraine's economic security system. An important role in this aspect is given to some domestic law enforcement agencies, whose work is carried out in various authorized areas. One of these is the interaction of these entities to counteract the threats to the economic component.

However, as of today, the national legal plane has not formed an adequate legal basis for effective law enforcement cooperation to counter threats to the economic security system of Ukraine. It seems that the implementation of the proposed changes should improve the level of performance of these entities, which should have a positive impact on the national economy. The results of scientific research may have theoretical implications for the analysis of issues such as:

1) administrative and legal regulation of the activity of law enforcement agencies as subjects of ensuring the system of economic security of Ukraine;

2) organization and cooperation of law enforcement agencies as subjects of economic security of Ukraine;

3) improvement of administrative and legal regulation of cooperation of law enforcement agencies on ensuring the system of economic security of Ukraine;

4) forms of cooperation between law enforcement agencies as 
subjects of ensuring the economic security of Ukraine.

This study does not imply any limitation on the subject composition of the use of the results obtained. This is due to the fact that a number of issues that may be of interest to representatives of different branches of science are analyzed.

\section{References:}

Bakanov I. (2020). The SBU did not allow to damage the state by 25.7 billion $\mathrm{UAH}$

https://ssu.gov.ua/ua/news/1/category/2/ view/7238\#.Y7eOj3m6.dpbs.

Bihus D. (2020). Economic crimes: how many billions Ukraine has lost through corruption.

https://24tv.ua/ru/ekonomichni_zlochini _skilki_miljardiv_ukraina_vtratila_cher ez_korupciju_n1126544.

Harust $\mathrm{Yu}$, Melnyk V, Kiiashko Yu, Halunko V. (2019). Economic crimes: Innovative mechanisms of counteraction by law enforcement agencies. Asia Life Sciences, 2, 247-263.
Harust YuV, Melnyk VI. (2019). Law enforcement agencies to protect Ukraine's economic security: administrative and legal aspects. Sumy: Publishing and Production Enterprise "Mriia", 256.

Huliahyn AY. (2015). Features of law enforcement in the field of administrative jurisdiction. Moscow: Academy of the Prosecutor General's Office of the Russian Federation, 441.

Khrebyna SV. (2006). The concept of "interaction" as a basic category of educational psychology. News of the Southern Federal University. Technical Science, 68(13), 155-160.

Klimchak M. (2019) World Economic Crime and Fraud Survey 2018: Survey Results of Ukrainian Organizations. Kyiv: Condor, 124.

Kniaziev S. (2020). Crime rate down $11 \%$ in 2019 compared to 2018 - first deputy head of the National Police. http://police.dn.ua/news/view/u-2019rotsi-riven-zlochinnosti-znizivsya-na11-vidsotkiv-porivnyano-z-2018rokompershij-zastupnik-glavinatspolitsii. 
Morozov VA. (2015). Interaction:

Korystin OY. (2010). Economic security.

https://pidruchniki.com/16850303/ekon omika/vzayemodiya_derzhavnih_pravo ohoronnih_organiv_viyavlennya_zapobi gannya_rozsliduvannya_ekonomichnih_ zlochiniv.

Kuchuk AM. (2007). Theoretical and legal foundations of law enforcement in Ukraine. Kyiv: Institute of Legislation of the Verkhovna Rada of Ukraine, 215.

Kulish AM. (2005). On the definition of "law enforcement". Law and Security, 5, 90-93.

Maliuha VM. (2016). Interaction of investigator with operational units and other subjects in the system of investigation of crimes. Lviv: Lviv National University named after I. Franko, 289.

Marchenko BM. (2009). Administrative activity of the state border guard service of Ukraine. Dnipro: Dnipropetrovsk State University of Internal Affairs. 223 p. concept, types and properties. Creative Economy, 9(10), 1309-1318.

Nazar YS. (2006). Interaction of territorial internal affairs bodies with local executive bodies and local selfgovernment bodies in the prevention of administrative offenses. Lviv: Lviv National University named after I. Franko 210.

Oliinyk VM. (2012). Concepts and principles of interaction in the detection and disclosure of crimes in the field of economic activity. Law Forum, 2, 511518.

Order of the Ministry of Internal Affairs of Ukraine and the Central Administration of the Security Service of Ukraine "On Approval of the Instruction on the Cooperation of Law Enforcement Agencies in the Fight against Organized Crime" No. 317/235. (2011). https://zakon.rada.gov.ua/laws/show/z0 822-11.

Orlova OO. (2008). Legal education and the role of the police in its implementation at the present stage of society development (theoretical and 
applied aspects). Kyiv: Kyiv National University of Internal Affairs 216.

Report of the National Anti-Corruption Bureau of Ukraine for the second half of 2019. (2019). https://nabu.gov.ua/sites/default/files/re ports/zvit_0.pdf.

Results of the work of the tax police for 2019. (2019). http://sfs.gov.ua/mediatsentr/novini/392865.html.

Rossokha SV. (2016). Law enforcement agencies of the state in the mechanism of protection of human and citizen's rights and freedoms. Kharkiv: Kharkiv National University of Internal Affairs, 230.

Saltevskyi MV. (2005). Forensic science (today). Kyiv: Condor, 588.

Syroid T, Kolomiets Yu, Kliuiev O, Myrhorod-Karpova V. (2019). International financial institutions as subjects of the financial system of the state. Asia Life Sciences, 2, 74-82.

World Bank forecasts 3.7\% GDP growth in Ukraine in 2020. (2020). https://www.ukrinform.ua/rubric- economy/2821254-svitovij-bankprognozue-u-2020-roci-zrostanna-vvpukraini-na-37.html 